\title{
Behaviour of Brasses Corrosion in Nitric Acid with and without PMT
}

\author{
M. Mihit, ${ }^{a}$ M. Belkhaouda, ${ }^{\text {L L. Bazzi, }},{ }^{\text {R }}$ R. Salghi, ${ }^{\text {, }}{ }^{*}$ S. El Issami, ${ }^{a}$ E. Ait Addi ${ }^{\text {a }}$ \\ a) Laboratoire Matériaux \& Environnement, Equipe de Chimie Physique Appliquée, Faculté des \\ Sciences, BP 8106, Agadir-Morocco. \\ b) Laboratoire d'Ingénierie des Procédés de l'Energie et de l'Environnement, Ecole National \\ des Sciences Appliquées d'Agadir, BP 1136, Agadir-Morocco
}

\begin{abstract}
The comparative study of corrosion behaviour of brasses $70 \mathrm{Cu} 30 \mathrm{Zn}$ and $60 \mathrm{Cu} 40 \mathrm{Zn}$ in $\mathrm{HNO}_{3}$ solution in absence and in presence of 1-phenyl-5-mercapto-1,2,3,4-tetrazole (PMT) was studied by gravimetric and electrochemical methods. Results obtained are in good agreement and reveal that the corrosion rate depends on immersion time and zinc content in the alloy. Copper and zinc losses from each specimen studied, at various immersion times, were estimated by Atomic Adsorption Spectroscopic analysis. This shows that the inhibition efficiency of the inhibitor towards copper is more significant than zinc. PMT was adsorbed preferentially on the copper surface and inhibits the process of corrosion of brasses in the nitric acid medium.
\end{abstract}

Keywords: brass, corrosion, inhibition, PMT.

\section{Introduction}

Copper is easily combined with many metals. It forms with zinc brasses which have a higher corrosion resistance and a very easy manufacture. Moreover, brasses are harder and solid. But their exhibition in acid media creates problems of corrosion [1-8]. When the brasses, containing more than $15 \%$ of zinc, are exposed in corrosive environments, they are affected not only by general corrosion damage, but also by dezincification process involving preferential dissolution of zinc, leaving a spongy mass of copper on the alloy surface [9]. Saber et al. [10] have studied the behaviour of copper-zinc alloy in nitric medium and suppose that the reactivity of $\mathrm{HNO}_{3}$ towards copper depends on the

\footnotetext{
*Corresponding author. E-mail address: r_salghi@yahoo.fr, salghi@ensa-agadir.ac.ma
} 
autocatalytic production cycle of $\mathrm{NO}_{2}$. Thus, copper dissolves in $\mathrm{HNO}_{3}$ according to:

$$
\begin{aligned}
\mathrm{Cu} & \longrightarrow \mathrm{Cu}^{2+}+2 \mathrm{e}^{-} \\
\mathrm{H}^{+}+\mathrm{e}^{-} & \longrightarrow \mathrm{H} \\
\mathrm{HNO}_{3}+\mathrm{H} & \longrightarrow \mathrm{H}_{2} \mathrm{O}+\mathrm{NO}_{2}
\end{aligned}
$$

However, zinc rigorously dissociates in $\mathrm{HNO}_{3}$ as follows:

$$
\begin{aligned}
\mathrm{Zn} & \longrightarrow \mathrm{Zn}^{2+}+2 \mathrm{e}^{-} \\
\mathrm{H}^{+}+\mathrm{e}^{-} & \longrightarrow \mathrm{H} \\
\mathrm{HNO}_{3}+8 \mathrm{H} & \longrightarrow \mathrm{NH}_{3}+3 \mathrm{H}_{2} \mathrm{O}
\end{aligned}
$$

$\mathrm{HNO}_{3}$ is more reactive to zinc than copper. The elimination of $\mathrm{H}$ by reactions (3) and (6) encourages the reaction (4) over the reaction (1) involving a strong dezincification [11]. Other authors noted that $\mathrm{HNO}_{2}$ present in the solution, is very unstable and active chemically at the same time, sudden a decomposition to produce $\mathrm{NO}_{3}^{-}$[12]. These anions are complexed with $\mathrm{Cu}^{2+}$ and $\mathrm{Zn}^{2+}$ according to reactions $(7)$ and $(8)$ :

$$
\begin{aligned}
& \mathrm{Cu}^{2+}+\mathrm{NO}_{3}^{-} \longleftrightarrow\left[\mathrm{Cu}\left(\mathrm{NO}_{3}\right)\right]^{+} \quad \log \mathrm{K}=-0.01 \\
& \mathrm{Zn}^{2+}+2 \mathrm{NO}_{3}^{-} \longleftrightarrow\left[\mathrm{Zn}\left(\mathrm{NO}_{3}\right)_{2}\right] \quad \log \mathrm{K}=-0.05
\end{aligned}
$$

The inhibition effect of the heterocyclic compounds is based on their chelating action and on the formation of an insoluble film on the electrode surface preventing the oxidation of the metal [13]. Thus, a barrier is easily formed by the heterocyclic molecules which contain the heteroatomes as nitrogen or sulphur [14]. The inhibitors such as imidazole [15,16], triazole [17-20] and pyrazole [21] act on the surface of copper and brasses by formation of films. Azoles are thus excellent agents of complexation on the surface of these metals.

In our laboratory, we have mainly focused on the application of tetrazole derivatives as corrosion inhibitors for copper and its alloys in different medium. The inhibition efficiency of 1-phenyl-5-mercapto-1,2,3,4-tetrazole (PMT) was always found more important in comparison with other derivative compounds as 1,2,3,4-tetrazole (TTZ), 5-amino-1,2,3,4-tetrazole (AT) and 1-phenyl-1,2,3,4tetrazole (PT) [22-24]. The aim of this work is to study the corrosion behaviour of the brasses $70 \mathrm{Cu} 30 \mathrm{Zn}$ and $60 \mathrm{Cu} 40 \mathrm{Zn}$ in nitric medium with and without the addition of PMT by using gravimetric and electrochemical measurements. 


\section{Experimental}

Polarization curves were recorded with a potentiostat PGP 201, piloted by computer. The scan rate is $60 \mathrm{mV} / \mathrm{min}$ and the potential ranged from -800 to $+500 \mathrm{mV} / \mathrm{SCE}$. Before recording each curve, the working electrode is maintained with its free potential of corrosion. We used for all electrochemical tests a cell with three electrode thermostats with double wall (tacussel standard CEC/TH). Saturated calomel electrode (SCE) and platinum electrode are used as reference and auxiliary electrodes, respectively. The surface and the composition of the working electrodes are given in Table 1.

Table 1. Chemical composition (in weight percent) studied

\begin{tabular}{lcccccc}
\hline Specimens & $\mathrm{Cu}$ & $\mathrm{Zn}$ & $\mathrm{Fe}$ & $\mathrm{Sn}$ & $\mathrm{Al}$ & $\mathrm{Pb}$ \\
\hline Pure $\mathrm{Cu}$ & 99.9 & 0.04 & 0.03 & - & 0.03 & - \\
$70 \mathrm{Cu} 30 \mathrm{Zn}$ & 70 & 28.95 & 0.06 & 0.9 & 0.02 & 0.07 \\
$60 \mathrm{Cu} 40 \mathrm{Zn}$ & 60 & 39.50 & 0.20 & 0.2 & 0.10 & - \\
Pure $\mathrm{Zn}$ & - & 99.90 & 0.30 & 0.3 & 0.20 & 0.20 \\
\hline
\end{tabular}

Gravimetric tests were carried out in double distilled walled glass cell equipped with a thermostatic cooling condenser. The solution volume was $75 \mathrm{~mL}$. Prior each measurement, specimens were abraded successively with fine emery papers. Then, the sheets were rinsed with acetone and distilled water, degreased and dried before being weighed and immersed in the corrosive medium. The weight-loss and the corrosion rate were determined from solution analysis by atomic absorption spectroscopy.

The corrosive solution $0.1 \mathrm{M} \mathrm{HNO}_{3}$ was obtained by dilution of analytical grade $65 \% \mathrm{HNO}_{3}$ of mark Taoura with distilled water. All experiments have been performed at the temperature $25 \pm 1{ }^{\circ} \mathrm{C}$. The organic compound 1-phenyl-5mercapto- 1,2,3,4-tetrazole (PMT) tested as inhibitor is the "Aldrich" commercial product. Its molecular structure is shown in Fig. 1.

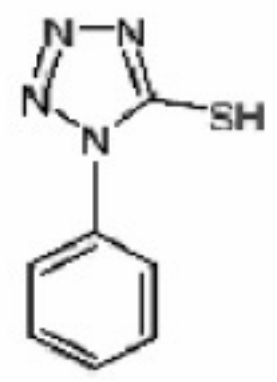

Figure 1. Molecular structure of 1-phenyl-5-mercapto-1,2,3,4-tetrazole (PMT). 


\section{Results and discussions}

\section{Polarization measurements}

Fig. 2 and Fig. 3 represent, respectively, the polarization plots of $70 \mathrm{Cu} 30 \mathrm{Zn}$ and $60 \mathrm{Cu} 40 \mathrm{Zn}$ in $0.1 \mathrm{M} \mathrm{HNO} 3$ with and without PMT at $10^{-3} \mathrm{M}$ after 24 hours of immersion. Cathodic current-potential curves give rise to Tafel lines indicating that the hydrogen evolution is activation-controlled.

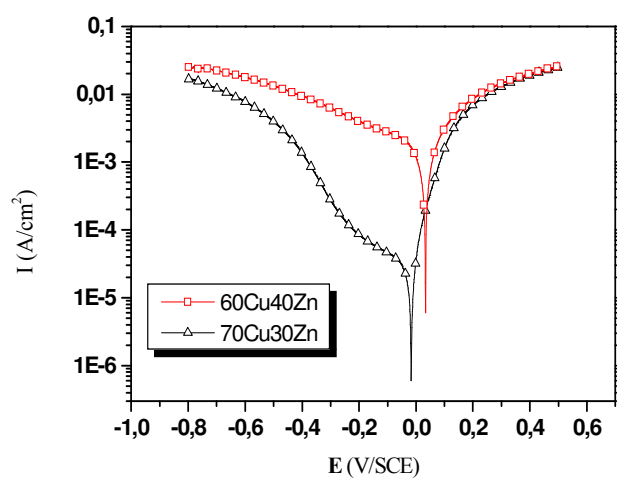

Figure 2. Polarization plots of brasses studied in $0.1 \mathrm{M} \mathrm{HNO}_{3}$ after $24 \mathrm{~h}$ of immersion.

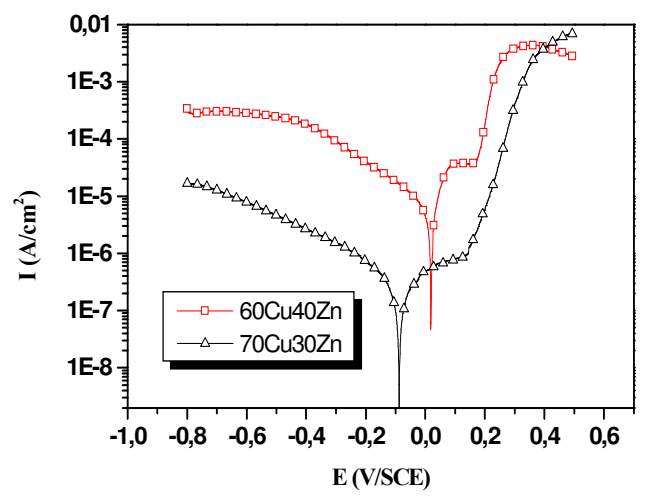

Figure 3. Polarization plots of brasses studied in $0.1 \mathrm{M} \mathrm{HNO}_{3}+10^{-3} \mathrm{M}$ PMT after $24 \mathrm{~h}$ of immersion.

Electrochemical parameters derived from Fig. 2 and Fig. 3 are gathered in Table 2. The corrosion inhibition efficiency $\mathrm{E}_{\mathrm{I}}(\%)$ was defined as:

$$
\mathrm{E}_{I}(\%)=\left(1-\frac{I_{\text {corr }}^{\prime}}{I_{\text {corr }}}\right) \times 100
$$

where $I_{\text {corr }}$ and $I_{\text {corr }}$ are, respectively, the uninhibited and inhibited corrosion current densities determined by extrapolation of the cathodic Tafel lines to corrosion potential $\left(E_{\text {corr }}\right)$.

Table 2 indicates that the corrosion rates of $60 \mathrm{Cu} 40 \mathrm{Zn}$ alloy are greater than those of $70 \mathrm{Cu} 30 \mathrm{Zn}$ in the corrosive medium with and without the addition of the inhibitor. These results demonstrate that $60 \mathrm{Cu} 40 \mathrm{Zn}$ is less resisting against the effect of nitric medium. On the other hand, we noted that PMT inhibited the corrosion of tow brasses with a value exceeding $99 \%$.

Table 2. Corrosion data of the tow brasses studied in $0.1 \mathrm{M} \mathrm{HNO}_{3}$ with and without addition of $10^{-3} \mathrm{M}$ PMT.

\begin{tabular}{cccccc}
\hline \multicolumn{1}{c}{ alloys } & solution & $\begin{array}{c}\mathrm{E}_{\text {corr }} \\
(\mathrm{V} / \mathrm{SCE})\end{array}$ & $\begin{array}{c}I_{\text {corr }} \\
\left(\mu \mathrm{A} / \mathrm{cm}^{2}\right)\end{array}$ & $\begin{array}{c}\beta \mathrm{c} \\
(\mathrm{mV} / \mathrm{dec} .)\end{array}$ & $\begin{array}{c}\mathrm{E}_{\mathrm{I}} \\
(\%)\end{array}$ \\
\hline \multirow{2}{*}{$70 \mathrm{Cu} 30 \mathrm{Zn}$} & Blank (S) & -0.018 & 44 & -133 & - \\
& $(\mathrm{S})+\mathrm{PMT}$ & -0.088 & 0.4 & -135 & 99.1 \\
\multirow{2}{*}{$60 \mathrm{Cu} 40 \mathrm{Zn}$} & Blank (s) & 0.032 & 2130 & -145 & - \\
& $(\mathrm{S})+$ PMT & 0.018 & 9 & -133 & 99.6 \\
\hline
\end{tabular}




\section{Weight loss measurement}

The evolution of the corrosion rate of brasses $70 \mathrm{Cu} 30 \mathrm{Zn}$ and $60 \mathrm{Cu} 40 \mathrm{Zn}$ with immersion time, in nitric acid with and without PMT at $10^{-3} \mathrm{M}$, is shown in Fig. 4 and Fig. 5. It's clear, in both cases, that the corrosion rate of $60 \mathrm{Cu} 40 \mathrm{Zn}$ is always more important than that of $70 \mathrm{Cu} 30 \mathrm{Zn}$. This difference in resistance is due to the zinc content in the alloy. Other studies found that the corrosion rate depends on the zinc content in the alloy $[9,26]$.

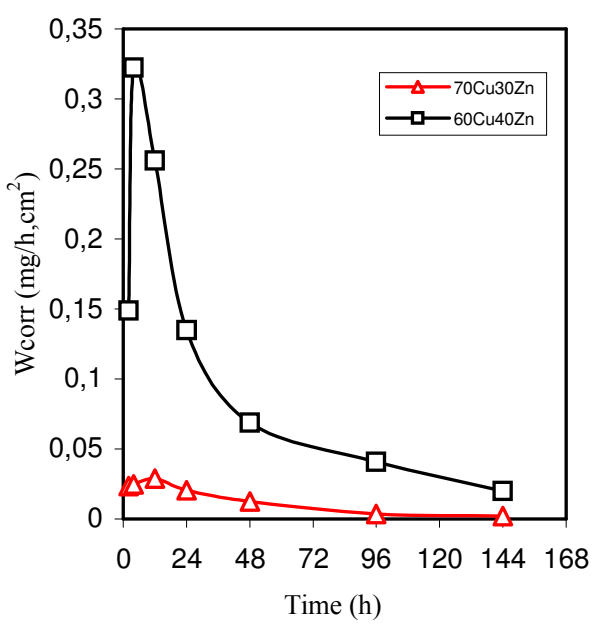

Figure 4. Variation of corrosion rate of brasses $(\mathrm{Cu}$ and $\mathrm{Zn}$ dissolution) with immersion time in $0.1 \mathrm{M} \mathrm{HNO}_{3}$.

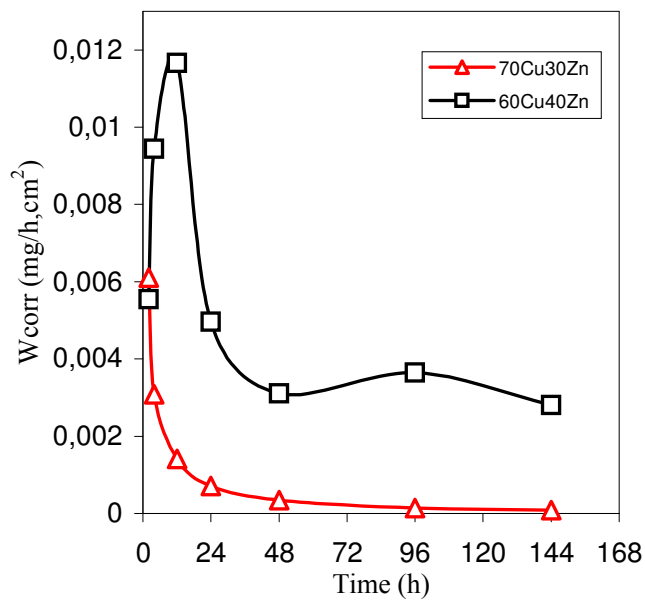

Figure 5. Variation of corrosion rate of brasses ( $\mathrm{Cu}$ and $\mathrm{Zn}$ dissolution) with immersion time in $0.1 \mathrm{M} \mathrm{HNO}_{3}$ $+10^{-3} \mathrm{M}$ PMT.

Figs. 4 and 5 indicate that the evolution of corrosion rate with the immersion time presents the maximum Wmax at a critical time Tc. Table 3 gives the value of these times Tc in the case of both $70 \mathrm{Cu} 30 \mathrm{Zn}$ and $60 \mathrm{Cu} 40 \mathrm{Zn}$. The addition of PMT causes change on the value of the critical time Tc. This period increases from 5 to 10 hours in the case of $60 \mathrm{Cu} 40 \mathrm{Zn}$ and it decreases from 12 to 2 hours in the case of $70 \mathrm{Cu} 30 \mathrm{Zn}$. For times superior at Tc, the corrosion rate decreases; this decrease is probably due to the formation of a deposit of the corrosion product on the metallic surface. In order to have an adequate explanation, we made quantitive analysis of copper and zinc components in the solution by atomic absorption spectroscopy.

Table 3. Critical time Tc related to $70 \mathrm{Cu} 30 \mathrm{Zn}$ and $60 \mathrm{Cu} 40 \mathrm{Zn}$ in $0.1 \mathrm{M} \mathrm{HNO}_{3}$ with and without $10^{-3} \mathrm{M}$ PMT.

\begin{tabular}{ccc}
\cline { 2 - 3 } & \multicolumn{2}{c}{ Critical time $\mathrm{T}_{\mathrm{c}}(\mathrm{h})$} \\
\cline { 2 - 3 } $70 \mathrm{Cu} 30 \mathrm{Zn}$ & Blank & Blank + PMT \\
\hline $60 \mathrm{Cu} 40 \mathrm{Zn}$ & 5 & $<2$ \\
\hline
\end{tabular}

Figs. 6 and 7 show the evolution of corrosion rate of the components (dissolved $\mathrm{Cu}$ and $\mathrm{Zn}$ ) of both $70 \mathrm{Cu} 30 \mathrm{Zn}$ and $60 \mathrm{Cu} 40 \mathrm{Zn}$ as a function of the exposure time 
in nitric acid in absence and presence of PMT, respectively. In the blank solution (Fig. 6), the corrosion rate of copper is important compared with zinc from the first minutes of immersion in the case of $70 \mathrm{Cu} 30 \mathrm{Zn}$, whereas the corrosion rate of copper is also important, but only after 3 hours of immersion time of $60 \mathrm{Cu} 40 \mathrm{Zn}$. These results explain that the zinc corrodes more selectively than copper $[4,9,27]$. The addition of PMT at $10^{-3} \mathrm{M}$ slows down the dissolution rate of both components $(\mathrm{Cu}$ and $\mathrm{Zn})$; however, we noted that the corrosion rate of zinc, in this case, is more important than that of copper. It is suggested in this subject that PMT has a selective protection of the site in which copper exists.

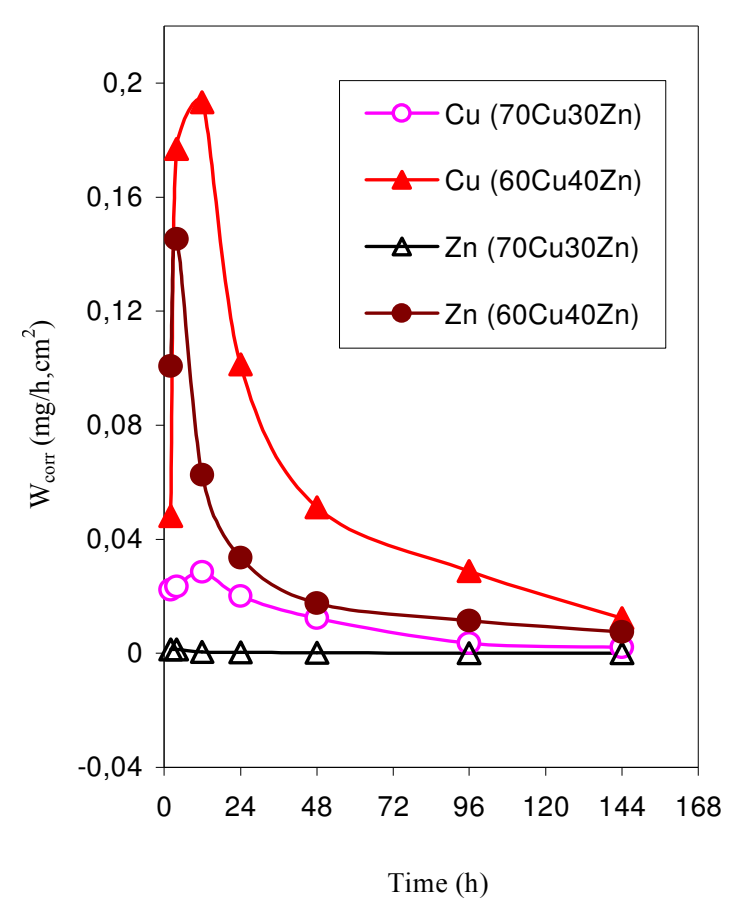

Figure 6. Variation of $\mathrm{Cu}$ and $\mathrm{Zn}$ dissolution from $70 \mathrm{Cu} 30 \mathrm{Zn}$ and 6OCu40Zn brasses with immersion time in $0.1 \mathrm{M} \mathrm{HNO}_{3}$.

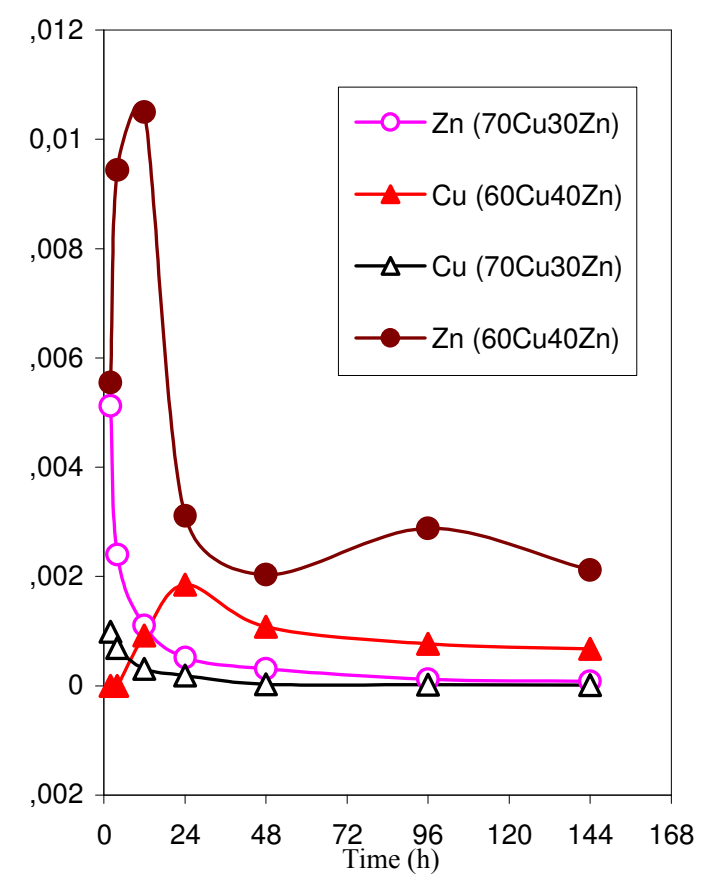

Figure 7. Variation of $\mathrm{Cu}$ and $\mathrm{Zn}$ dissolution from $70 \mathrm{Cu} 30 \mathrm{Zn}$ and 6OCu40Zn brasses with immersion time in $0.1 \mathrm{M} \mathrm{HNO}_{3}+10^{-3} \mathrm{M}$ PMT.

The values of critical immersion time Tc, relating to the maximum of the corrosion rate of copper and zinc components relating to each specimens, are gathered in table 4 . It is noted that Tc values, related to $60 \mathrm{Cu} 40 \mathrm{Zn}$ components, increase in the presence of PMT. However, Tc values decrease in the case of the constituents of $70 \mathrm{Cu} 30 \mathrm{Zn}$. In this connection, it is suggested that the alloy requires minimum and enough time to the dissolution of superficial zinc, then the PMT adsorbs on the alloy surface which is rich of copper; therefore, the alloy containing $40 \%$ of zinc needs more time than that containing $30 \%$. This is the reason why the PMT inhibitor prevents quickly the dissolution of $70 \mathrm{Cu} 30 \mathrm{Zn}$ components. 
Table 4. Critical time Tc values relating to the dissolution of $\mathrm{Cu}$ and $\mathrm{Zn}$ constituents in the case of $70 \mathrm{Cu} 30 \mathrm{Zn}$ and $60 \mathrm{Cu} 40 \mathrm{Zn}$ in $0.1 \mathrm{M} \mathrm{HNO}_{3}$ with and without PMT at $10^{-3} \mathrm{M}$.

\begin{tabular}{llcc}
\cline { 3 - 4 } & & \multicolumn{2}{c}{ Critical time Tc (h) } \\
\cline { 3 - 4 } & & Blank & Blank + PMT \\
\hline \multirow{2}{*}{$70 \mathrm{Cu} 30 \mathrm{Zn}$} & $\mathrm{Cu}$ & 12 & $<2$ \\
& $\mathrm{Zn}$ & $<2$ & $<2$ \\
\multirow{2}{*}{$60 \mathrm{Cu} 40 \mathrm{Zn}$} & $\mathrm{Cu}$ & 10 & 24 \\
& $\mathrm{Zn}$ & 5 & 10 \\
\hline
\end{tabular}

Fig. 8 illustrates the evolution of the inhibition efficiency $\left(\mathrm{E}_{\mathrm{w}} \%\right)$ of PMT towards the dissolution of $\mathrm{Cu}$ and $\mathrm{Zn}$ from $70 \mathrm{Cu} 30 \mathrm{Zn}$ and $60 \mathrm{Cu} 40 \mathrm{Zn}$ as a function of the immersion time. The value of $\left(\mathrm{E}_{w} \%\right)$ is calculated as follows:

$$
\mathrm{E}_{w}(\%)=\left(1-\frac{W_{\text {corr }}^{\prime}}{W_{\text {corr }}}\right) \times 100
$$

where $\mathrm{W}_{\text {corr }}$ and $\mathrm{W}^{\prime}$ corr are, respectively, the uninhibited and inhibited corrosion rate of the component $(\mathrm{Cu}$ or $\mathrm{Zn})$.

Fig. 8 shows the evolution of the inhibition efficiency of PMT, with immersion time, towards components of each alloy studied. We concluded that the PMT protection towards copper component is more significant in comparison with zinc. Consequently, the inhibition efficiency related to zinc decreases while the zinc content increases in the alloy.

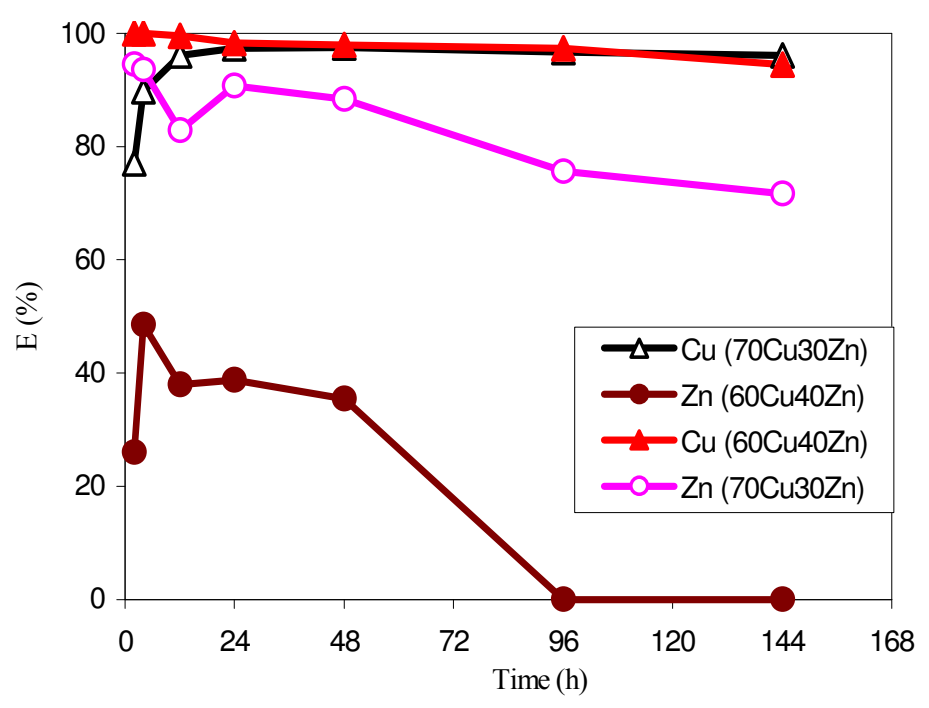

Figure 8. Evolution of the inhibition efficiency of PMT of alloys' components with the immersion time.

Gravimetric survey of the behaviour of pure copper and zinc

According to the experimental methods used, we investigated the corrosion and the corrosion inhibition of pure copper and zinc using PMT at $10^{-3} \mathrm{M}$ under the same experimental conditions. Fig. 9 and Fig. 10 illustrate, respectively, the 
evolution of the corrosion rate of both pure metals studied as a function of immersion time. The addition of PMT slows down the kinetic of copper dissolution. However, the behaviour of the zinc doesn't change. We noted that PMT is not adsorbed on the zinc surface. The immersion time Tc relating to the maximum corrosion rate is unchanged either for pure copper or zinc. These results explain that the variation of Tc related to the studied brasses is due essentially to simultaneous existence of copper and zinc in the alloys.

These observations are consistent with other author's results [13,27,28]. They found that there is the formation of $\mathrm{Cu}$-PMT complex on the surface, especially with the heteroatom of PMT (N and S) $[13,29]$. This result suggests that the PMT coordination compound film stabilizes $\mathrm{Cu}^{+}$and blocks the substrate electrochemical reaction, thus preventing the metal from corrosion.

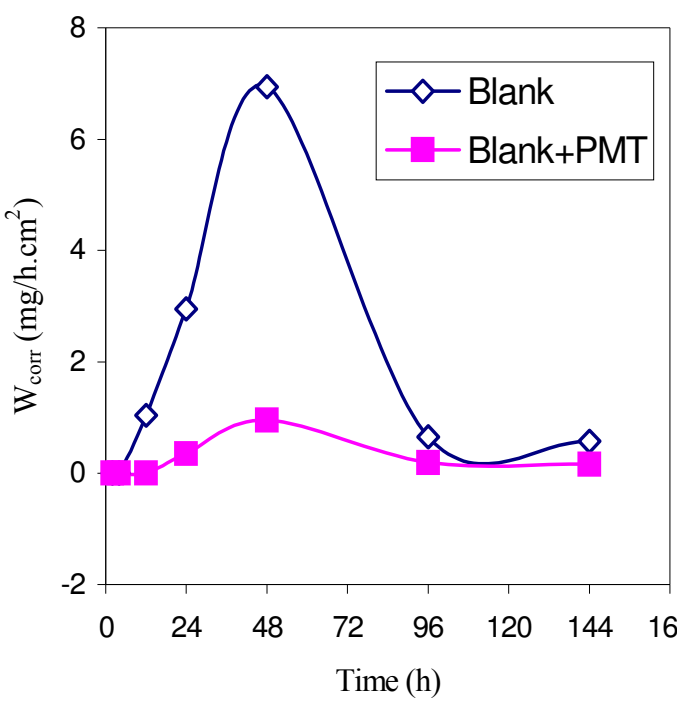

Figure 9. Evolution of corrosion rate of pure copper with the immersion time in $0.1 \mathrm{M} \mathrm{HNO}_{3}$ with and without the addition of $10^{-3}$ M of PMT.

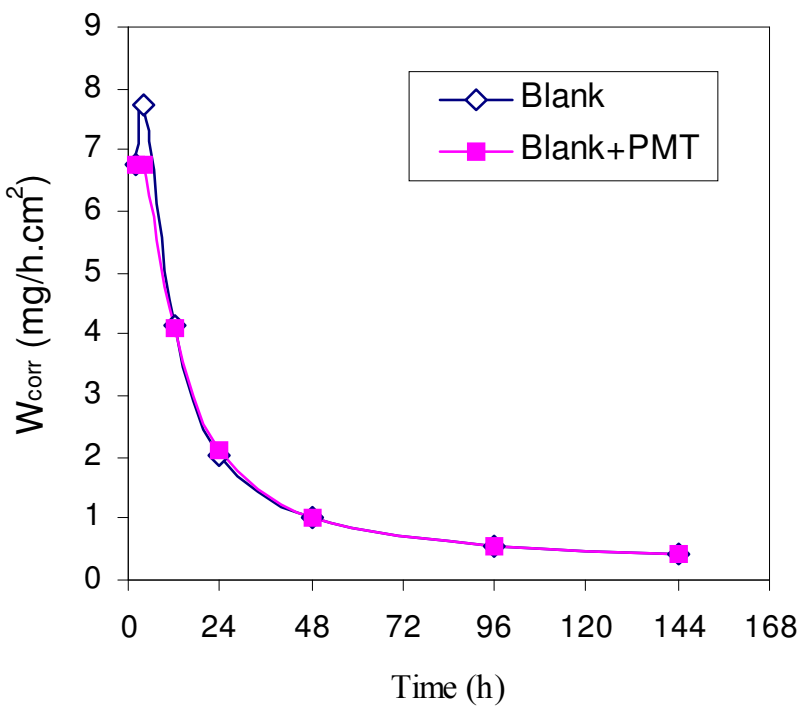

Figure 10. Evolution of corrosion rate of pure zinc with the immersion time in $0.1 \mathrm{M}$ $\mathrm{HNO}_{3}$ with and without the addition of $10^{-3}$ M of PMT.

\section{Conclusion}

The main findings of the present work can be summarized as follows:

1. $0.1 \mathrm{M} \mathrm{HNO} 3$ is a corrosive medium to $70 \mathrm{Cu} 30 \mathrm{Zn}$ and $60 \mathrm{Cu} 40 \mathrm{Zn}$ alloys.

2. The corrosion rate depends on the immersion time and on the zinc content in the alloy.

3. The addition of PMT slows down the oxidation of brasses.

4. The PMT adsorbs and protects copper, however it remains with no effect on the zinc. 


\section{References}

1. S. Kertit, H. Essoufi, B. Hammouti and M. Benkaddour,. Chim. Phys. 95 (1998) 2070.

2. R. Karpagavalli, S. Rajeswari, Anti-corr. Meth. and Mat. 45 (1998) 333.

3. W.A. Badawy, F.M. Al-kharafi, Corrosion Science 55 (1999) 268.

4. M.I. Abbas, Br. Corr. J. 26 (1991) 273.

5. S. Kertit, B. Hammouti, Applied Surf. Sci. 93 (1996) 59.

6. S.S. El-Egamy, A.S. El-Azeb, W.A. Badawy, Corrosion Science 50 (1994) 468.

7. S. El Issami, L. Bazzi, M. Mihit, M. Hilali, R. Salghi, E. Ait Addi, Physique IV 123 (2003) 307.

8. Y. Abed, Z. Anaz, B. Hammouti, A. Aouinti, S. Kertit, A. Mansri, J. Chim. Phys. 96 (1999) 96.

9. S.N. Banerjee, "An introduction to science of corrosion and its inhibition" Oxanian Press, New Delhi, (1985) P 286; P.T. Gilbert in "Corrosion" (Eds.) L.L. Shreir, Newness-Butterworths, London (1979) 4:46

10. T.M.H. Saber, A.A. El Warraky, Brit. Corr. J. 26 (1991) 279.

11. A.M. Shams El Din, A.E. El Hosary, M.M. Gawish, Corrosion Science 16 (1976) 845.

12. B. Malki, Thèse de doctorant es sciences, sciences des matériaux, Lille, (1999).

13. X.R. Ye, X.Q. Xin, J.J. Zhu, Z.L. Xue, Applied Surf. Sci. 135 (1998) 307.

14. I. Popova, J.T. Yates, J. Langmuir 13 (1997) 6169.

15. E. Stupnisek-Lisac, A. Gazivoda, M. Madzarac, Electrochimica Acta 47 (2002) 4189.

16. G. Lewis, Corrosion Science 22 (1982) 579.

17. A.M. Fenelon, C.B. Breslin, J. Applied Electrochem. 8 (2001) 509.

18. H.S. Hegazy, E.A. Ashour, B.G. Ateya, Applied Electrochem. 5 (2001)1265.

19. R. Ravichandran, S. Nanjundan, N. Rajendran, Applied Surf. Sci. 236 (2004) 241.

20. G.K. Gomma, Material Chemistry and Physics 56 (1998)27.

21. A. Dafali, B. Hammouti, R. Touzani, S. Kertit, A. Ramdani, K. El Kacemi, Anti-Corrosion Methods and Materials 49 (2002) 96.

22. M. Mihit, S. El Issami, M. Bouklah, L. Bazzi, B. Hammouti, E. Ait Addi, R. Salghi, S. Kertit, Applied Surf. Sci. 252 (2005) 2389.

23. S. El Issami, L. Bazzi, M. Mihit, M. Hilali, R. Salghi, E. Ait Addi, J. Phys. IV France 123 (2005) 307.

24. M. Mihit, R. Salghi, S. El Issami, L. Bazzi, B. Hammouti, E. Ait Addi, S. Kertit, Pigment and Resin Technoloy 35 (2006)151.

25. S. El Issami, M. Mihit, L. Bazzi, R. Salghi, M. Hilali, E. Ait Addi, Transaction of SAEST 40 (2005) 24. 
26. J. Sugawra, H. Ebike, Corrosion Science 7 (1967) 513.

27. R. Karpagavalli, S. Rajeswari, Bulletin of Electrochemistry 15 (1999) 56.

28. E.S. Raper, Coord. Chem. Rev. 61 (1985) 115.

29. J.L. Fang, X.R. Ye, J. Fang, Y.L. Chen, J. Nanjin Univ. 28 (1992) 569. 